state. Information on inpatient and outpatient waiting times by specialty and consultant was sent, every three months, to local general practitioners, who had the additional benefit of a direct, ex-directory telephone link to the centre to make inquiries. Other equally cogent suggestions for improvements in information systems and outpatient waiting list management have been voiced but have gone, it seems, unheard. ${ }^{4-6}$

The NHS is modelled on the "patient patient." When it was born rationing was a part of everyday life and people queued quietly for health care just as in the war they had queued for food. Consumerism, medical progress, and the Patient's Charter make delay less acceptable. Patients are now being promised local charter standards for waiting times for first outpatient appointments and maximum clinic waiting times of 30 minutes. $^{7}$ The workshop participants rightly urge caution in setting national standards for outpatient waiting times, in favour of targets which could "allow differential rates of progress."

Waiting in one area is contingent on activity in others. The choices being made by purchasers and providers will have an impact, and in some places extra resources may be required. That said, there are opportunities to reduce outpatient waiting times. We have to find ways of managing waiting more effectively and keeping the customer (be it general practitioner or patient) informed. On the research agenda we need to look at organisation, information, and communication, and it may be time, as this new report suggests, to debate and reconsider the role of outpatient clinics. The ideas are there; now they must come out of academe and into the clinic.

CATHERINE POPE Research Fellow

Health Services Research Unit,

Department of Public Health and Policy,

London School of Hygiene and Tropical Medicine,

London WC1E 7HT

1 Royal College of General Practitioners. European study of referrals from primary to secondary care. London: Royal College of General Practitioners, 1992 (Occasional Paper No 56).

German K, Nuwahid F, Matthews P, Stephenson T. Dangers of long waiting times for outpatient appointments at a urology clinic. BMF 1993;306:429.

2 Wilkin D, Roland M. Waiting times for first outpatient appointments in the NHS. Manchester: Centre for Primary Care Research, University of Manchester, 1993.

3 Department of Health and Social Security. Waiting for hospital treatment. London: DHSS, 1980.

4 Shaw CD. The problem of out-patient visits. Health Trends 1981;13:107-8.

West R, McKibbin B. Shortening waiting lists in orthopaedic surgery outpatient clinics. BM 1982;284:728-30.

6 Department of Health and Social Security. Orhopaedic services: waiting time for outpatien appointments and inpatient treatment. London: HMSO, 1981.

7 Department of Health. The patient's charter. London: HMSO, 1992

\title{
Screening for hypertrophic cardiomyopathy
}

\author{
Not yet feasible
}

Last autumn the Hypertrophic Cardiomyopathy Association launched a campaign to raise awareness of hypertrophic cardiomyopathy and, together with the Sports Council's National Sports Medicine Institute, announced a pilot screening programme to detect the condition among young athletes. ' The association's aims are laudable: counselling and support, provision of information, promotion of increased awareness to both the public and doctors, and support for research. Specific screening campaigns, however, should be based on a logical, not purely emotional, response to tragic cases. Any screening programme needs to fulfil several clear conditions: the disease should be common (or important in its effects); there must be a reliable screening procedure to detect disease early; and treatment should be available to modify the outcome. Does hypertrophic cardiomyopathy meet these conditions?

Certainly the condition has potentially devastating effects, as the tragic cases of sudden death in apparently fit young people described by the association illustrate. ${ }^{1}$ However, the condition is not common. The incidence is estimated to be $2 \cdot 5 / 100000 /$ year with a prevalence of $20 / 100000 .^{2}$ The condition is associated with a high incidence of sudden death $\left(2.5 \%\right.$ per year in adults and $6 \%$ in children and adolescents $\left.{ }^{3}\right)$, and it is the commonest recognised cause of sudden death in competitive athletes. ${ }^{4}$ Sudden death associated with exercise is a major cause of death in hypertrophic cardiomyopathy, ${ }^{5}$ and as a result patients with the disease are recommended to avoid strenuous exercise. ${ }^{6}$

Screening for hypertrophic cardiomyopathy can be done either by echocardiography or by genetic screening. Echocardiography is superficially appealing since the technique is non-invasive and relatively cheap. It is, however, fraught with problems. Even in relatives of known patients there is heterogeneity in the echocardiographic findings. ${ }^{\text {. No }}$ systematic data are available on the population prevalence of possible echocardiographic criteria for diagnosing hypertrophic cardiomyopathy, but one study has found asymmetric septal hypertrophy in $8 \%$ of a general population with heart disease other than hypertrophic cardiomyopathy. ${ }^{7}$ Distinguishing between the hypertrophied heart of the athlete and hypertrophic cardiomyopathy can be difficult, ${ }^{8}$ and the athletic population is a proposed target for screening. An echo technique using analysis of diastolic flow patterns may be more sensitive. ${ }^{9}$ The natural history of the disease also makes it unsuitable for screening by imaging techniques: a normal scan now is no guarantee of a normal heart in the future. ${ }^{10}$ Electrocardiographic screening, while even cheaper and more widely available, is less specific and sensitive.

In about half of all cases hypertrophic cardiomyopathy is familial, the remaining cases presumably arising from sporadic mutation. ${ }^{11}$ In those families with a clear genetic link hypertrophic cardiomyopathy seems in many to be inherited as a dominant gene with a high degree of penetrance. ${ }^{12}$ The recent finding of mutations in the gene coding for $\beta$-myosin heavy chain in some families with the condition ${ }^{13}$ has both clarified the nature of the genetic defect and simultaneously raised the prospect of some form of genetic screening..$^{14}$ Of those families with documented familial hypertrophic cardiomyopathy, however, only about half have identifiable mutations related to the $\beta$-myosin heavy chain gene, ${ }^{13}{ }^{15}$ and little is known of the incidence of genetic abnormalities in non-familial cases. In familial cases without a gene defect regular echocardiograms are the only practicable screening method.

As yet there is little definitive evidence that treatment improves prognosis in patients with symptomatic hypertrophic cardiomyopathy. There are no data from prospective randomised controlled trials. A retrospective study showed that amiodarone was associated with a better prognosis in patients with documented ventricular tachycardia on 
electrocardiographic monitoring. ${ }^{16}$ In another study a group of children with hypertrophic cardiomyopathy at high risk of sudden death (history of loss of consciousness, family history of sudden death) who were given amiodarone had a better prognosis than an untreated group at low risk. ${ }^{17}$ But the case for amiodarone is not proved, and it has been associated with a higher incidence of sudden death. ${ }^{18} \mathrm{~A}$ high risk group can be identified on electrophysiological ${ }^{19}$ and haemodynamic grounds, ${ }^{20}$ and on the basis of a high risk family history. ${ }^{21}$ There is, however, no evidence that any therapeutic intervention benefits patients with asymptomatic hypertrophic cardiomyopathy, let alone those with only the genetic trait or borderline asymmetric septal hypertrophy. These are the subjects whom screening would detect in larger numbers than real cases.

Screening can have value in reassuring unaffected members of families where the genetic abnormality is known. It can also be used to guide controlled trials of promising treatments in affected members. Only once effective treatments are established, however-and this includes advice to avoid strenuous exerçise-should generalised screening be advised. Given the low incidence of the condition, lack of proved treatments, and low sensitivity and specificity of the available screening tests, widespread testing of the general population cannot yet be advised. Screening of athletes would detect only a small proportion of affected individuals, though it may reduce the risks of sudden death on exertion for those few. The major benefit would be in raising awareness of this potentially devastating condition.

A L CLARK Robert Luff Fellow

A J $S$ COATS

Viscount Royston and

British Heart Foundation Senior Lecturer

Department of Cardiac Medicine,

National Heart and Lung Institute,

London SW3 6LY
Dawson J. Campaign to raise awareness of hypertrophic cardiomyopathy. $B M 7$ 1992:305:793.

Codd MB, Sprague DD, Gersh BJ, Melton LJ. Epidemiology of idiopathic dilated and hypertrophic cardiomyopathy: a population based study in Olmstead County, Minnesota. Circulation 1989;80:564-72

3 McKenna WJ, Deanfield J, Faruqui A, England D, Oakley C, Goodwin J. Prognosis in hypertrophic cardiomyopathy: role of age and clinical, electrocardiographic and hemodynamic features. Am f Cardiol 1981;47:532-8.

4 Maron BJ, Roberts WC, McAllister HA, Rosing DR, Epstein SE. Sudden death in young athletes. Circulation 1980;62:218-29.

5 Shah PM, Adelman AG, Wigle ED, Gobel FM, Burchell HB, Hardarson T, et al. The natural (and unnatural) history of hypertrophic obstructive cardiomyopathy: a multicenter cooperative study. Circ Res 1974;34/35(suppl 2):179-95.

6 Maron BJ, Gaffney FA, Jeresaty RM, McKenna WJ, Miller WW. Task force II: hypertrophic cardiomyopathy, other myopericardial diseases and mitral valve prolapse. $f \mathrm{Am}$ Coll Cardio 1985;6:1215-7.

7 tenCate FJ, Hugenholtz PG, van Dorp WG, Roelandt J. Prevalence of diagnostic abnormalities in patients with genetically transmitted asymmetric septal hypertrophy. Am f Cardiol 1979;43 $731-7$

8 Shapiro LM. The differentiation of physiological from pathological left ventricular hypertrophy. In: Hunter $S$, Hall $R$, eds. Clinical echocardiography. Tunbridge Wells: Castle House, 1986:25-32

9 Lewis JF, Spirito P, Pelliccia A, Maron BJ. Usefulness of Doppler echocardiographic assessmen of diastolic filling in distinguishing "athlete's heart" from hypertrophic cardiomyopathy. Br Heart f 1992;68:296-300.

10 Maron BJ, Spirito P, Wesley Y, Arce J. Development and progression of left ventricula hypertrophy in children with hypertrophic cardiomyopathy. N Engl f Med 1986;315:610-4.

11 Greaves SC, Roche AHG, Neutze JM, Whitlock RML, Veale AMO. Inheritance of hypertrophic cardiomyopathy: a cross-sectional and $\mathrm{M}$ mode echocardiographic study of 50 families. Br Heart 1987;58:259-66

12 Clark CE, Henry WL, Epstein SE. Familial prevalence and genetic transmission of idiopathic hypertrophic subaortic stenosis. N Engl f Med 1973;289:709-14.

13 Watkins H, Rosenzweig A, Hwang DS, Levi T, McKenna W, Seidman CE, Seidman JG Characteristics and prognostic implications of myosin missense mutations in familial hypertrophic cardiomyopathy. N Engl f Med 1992;326:1108-14.

14 Rosenzweig A, Watkins H, Hwang DS, Miri M, McKenna W, Traill TA, et al. Preclinical diagnosis of familial hypertrophic cardiomyopathy by genetic analysis of blood lymphocytes. N Engl f Med 1991;325:1753-60.

5 Epstein ND, Fananapazir L, Lin HJ, Mulvihill J, White R, Lalouel JM, et al. Evidence of genetic heterogeneity in five kindreds with familial hypertrophic cardiomyopathy. Circulation 1992;85: 635-47.

16 McKenna WJ, Oakley CM, Krikler DM, Goodwin JF. Improved survival with amiodarone in patients with hypertrophic cardiomyopathy and ventricular tachycardia. $\mathrm{Br}$ Heart $\mathrm{f}$ 1985;53: 412-6.

17 McKenna WJ, Franklin RCG, Nihoyannopoulos P, Robinson KR, Deanfield JE. Arrhythmia and prognosis in infants, children and adolescents with hypertrophic cardiomyopathy. $7 \mathrm{Am}$ Coll Cardiol 1988;11:147-53.

18 Fananapazir L, Leon MB, Bonow R, Tracy CM, Cannon RO, Epstein SE. Sudden death during empiric amiodarone therapy in symptomatic hypertrophic cardiomyopathy. Am $\mathcal{f}$ Cardiol 1991;67:169-74.

19 Fananapazir L Chang AC, Epstein SE, McAreavey D. Prognostic determinants in hypertrophic cardiomyopathy. Prospective evaluation of a therapeutic strategy based on clinical, Holter, hemodynamic, and electrophysiological findings. Circulation 1992;86:730-40.

20 Romeo F, Pelliccia F, Cristofani R, Martuscelli E, Reale E. Hypertrophic cardiomyopathy: is a left ventricular outflow tract gradient a major prognostic determinant? Eur Heart f 1990;11:233-40.

21 Maron BJ, Lipson LC, Roberts WC, Savage DD, Epstein SE. Malignant hypertrophic cardiomyopathy: identification of a subgroup of families with unusually frequent premature deaths. Am F Cardiol 1978;41:1133-40.

\section{On not listening to patients}

\section{Putting patients first must be more than a slogan}

Last week a British psychiatrist was convicted of repeatedly sexually assaulting patients over a period of 12 years. ${ }^{1}$ One of the most disturbing features of the case was how patients' protestations of abuse were ignored. This may be the extreme consequence of a health service which, although it insists that it puts patients first, often doesn't do so at all.

Most of the patients assaulted by Dr Gordon Maden were young men with severe psychosocial problems-many of them drug addicts with a criminal record. People within the health and social services had been aware for years of the patients' accusations, but nothing was done. One patient who complained was told "to stop being silly." 2 A colleague of $\mathrm{Dr}$ Maden is quoted as saying that nothing was done because "nothing really terrible had happened. . . . The addicts weren't too cut up about it. They had to deal with more degrading things in their lives. And addicts are cunning, devious people. To be honest, I felt they could quite easily manipulate him." ${ }^{3}$ This is a long way from the central idea of total quality management-that the patient or customer is king. And homeless drug addicts must have as much right to the throne as Hampstead intellectuals.
Last week the House of Commons select committee on the ombudsman heard another story of neglect in the NHS. ${ }^{4}$ The health ombudsman's officer was investigating a case of a terminally ill woman who was moved from her ward in the King Edward VII Hospital in Windsor every weekend for 10 weeks because the ward was closed at weekends to save money. When the ombudsman reported on the case he said: "I cannot recall ever having encountered such a manifest and deplorable lack of regard by management for the welfare of a hospital inpatient." Last week's hearing was to examine why, when the ombudsman's officer was investigating the case, she was repeatedly interrupted by a nurse manager. Once again the NHS ignored the principle of total quality management and instead of learning from its mistakes was desperate to deny them.

These are both extreme examples, but there are probably hundreds of examples every day within the NHS of patients being ignored and treated brusquely. Trisha Greenhalgh describes two such cases on $\mathrm{p} 464$. In one case a woman waited three quarters of an hour with her child screaming with an undressed wound. The doctor eventually arrived and grumbled, 